\title{
Strada's Role in Projects Initiated by Emperor Ferdinand I
}

In the foregoing I have attempted to sketch the situation in the field of architecture and decoration at the Imperial court at the time Strada arrived in Vienna, somewhere in May 1558. He found that his new Habsburg patrons had developed a taste for more up-to-date architecture and decoration in the classical, Italian manner; a taste that was, however, difficult for them to satisfy. As we have seen, some of their architects and court-artists had some inkling of what was going on in this field both south of the Alps and elsewhere in Europe, at least by means of some of the recent illustrated publications on architecture and ornamental design. The most important among these were the first five books of Serlio's architectural treatise. The first volume of these had come out in 1537, and all five books were repeatedly reprinted in the fifth decade of the sixteenth century also in French and Flemish editions. ${ }^{1}$ But few, if any, of the architects at court had any first-hand experience of such developments, and some of them, such as the illiterate Benedikt Kölbl, would hardly have been able to profit even from the printed material.

In view of this lack of masters sufficiently acquainted with, let alone wellversed in the new manner, the arrival of an artist and designer who was both thoroughly acquainted with its theoretical aspects and had first-hand knowledge of its results, must have been quite welcome. As we have seen in Chapter 4, very soon after his arrival in Vienna Strada was repeatedly asked to advise, with other court-architects, on several of the projects being executed or planned at that time. When in January 1560 Strada was formally appointed as an architect, the salary he was conceded was similar to that of the other architects active at court. As Hilda Lietzmann has first pointed out, this makes it very unlikely that his tasks remained limited to such occasional advice. In the following a number of projects at court will be discussed in which Strada was involved.

1 The French and Flemish editions were published by Pieter Coecke van Aelst, who also printed the illustrated description of the Entry of Philip II in Antwerp in 1548, which doubtless was present in Vienna. Other authors whose books and prints may have reached Vienna by this time include Jacques Androuet du Cerceau, Jean Martin and Guillaume Philandrier. 


\subsection{The Hofspital}

The first documented instance of Strada's involvement in projects at court dates already from a year earlier, shortly after he had arrived in Vienna. The Hofspital or Kaiserspital, a charitable institution under the particular patronage of Queen Anna of Hungary and of Ferdinand himself that was located next to the Hofburg [ $\mathrm{nr} 5$ on the plan in Fig. 5.72] had been begun already in 1549, after a model designed by Sigismund de Preda, who presumably died shortly afterwards. Since then, all sorts of problems had held up its completion. On 20 October 1558 a model for its arcades, provided by Benedikt Kölbl, was the subject of a careful consultation between the Emperor himself, his Bausuperintendent Schallautzer, his court-painter and architect Pietro Ferrabosco and the recent arrival, Jacopo Strada. This commission approved Kölbl's plans, and the building was realized under Kölbl's direction in the following years. ${ }^{2}$

The Kaiserspital was very largely remodelled in the eighteenth century, and the little we know of its original appearance comes from a photograph taken during its demolition in 1903, when the original arcades of the courtyard became visible again, and from the measurements taken at the time by $\mathrm{Ru}-$ dolf Pichler, who used them for a set of reconstruction drawings [Fig. 6.1]. His

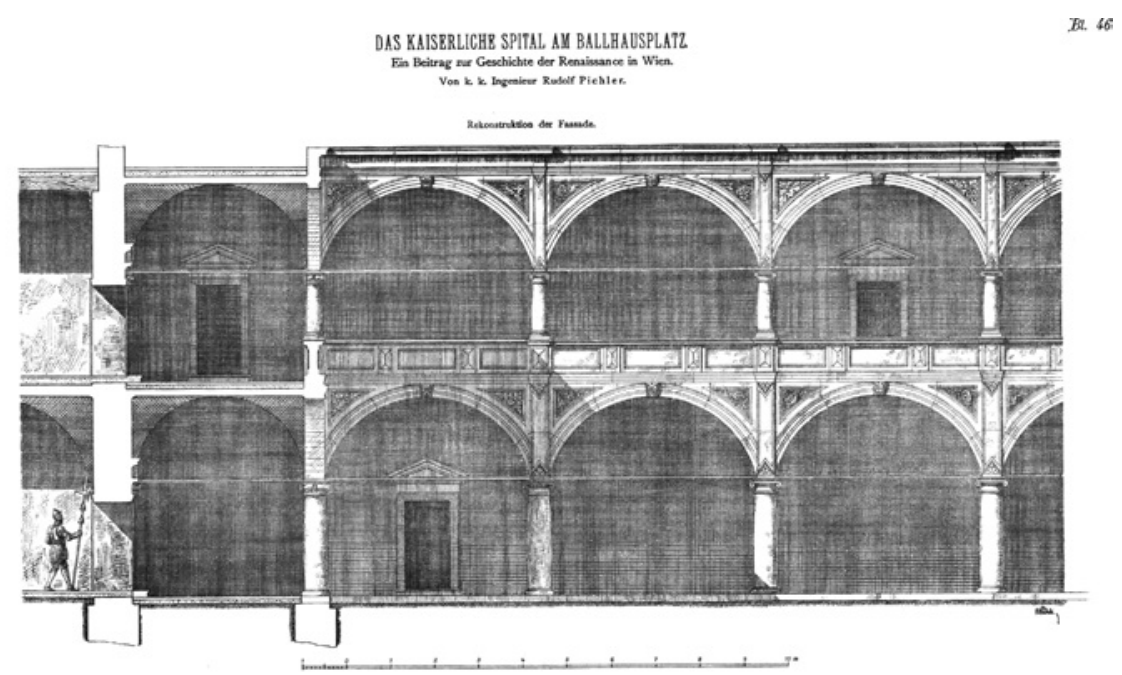

FIGURE 6.1 Rudolf Pichler, Reconstruction of the arcades of the Kaiserspital based on measurements made shortly before its demolition in 1903.

2 On the Hofspital, see: Pichler 1904; Kühnel 1958, pp. 314-315, 317-318 and 324; Kühnel 1971, pp. 37-38 and Fig. 6; Nowotny 1978; Wandruszka / Reininghaus 1984, pp. 16-32;Grün 2014. 
rendering of the courtyard shows a gallery of two superimposed arcades. The lower arcade is carried on Tuscan columns the height of which is difficult to determine; the upper story consists of wide, possibly segmental arches carried on short, squat columns topped by ionic capitals, of which in the photograph only two survive; the two orders are vertically connected by shallow pilaster strips. It is unlikely that a third story was part of the original building. This building thus conforms to the type of arcaded courtyard or Laubenhof that was, and would remain, so popular in Austria and Bohemia. Moreover it is undoubtedly a Renaissance design, with columns and capitals carrying segmental arches.

Nevertheless it is not very likely that such a facade would have greatly appealed to Strada's ideas. Though the architectural ornament, in particular the columns and their capitals, are not badly designed, their application can hardly be called classical, witness the arches carried on columns, the odd strips prolonging the columns upward, the apparent lack of an entablature between the two levels. Principal defect, from the point of view of classical, Vitruvian architecture, is the disproportion between the two orders: the columns of the first floor are far too short in relation both to their own capitals, and to the columns of the ground floor.

It is clear that if Strada protested against these defects, such protest was not heeded by his colleagues. But it can be argued that Strada may not have protested very strongly — after all, the building had been designed much earlier, was largely finished, and the model for its completion was presented by the principal architect serving the Emperor in Vienna. Moreover, Strada had only just arrived and would avoid the risk to offend his new colleagues immediately. By this time he must have realized that his rash attack on Wolfgang Lazius' antiquarian competence did not contribute to local good-will and did not endear him to the Emperor: in all probability he would not have risked to repeat such a blunder in the presence of his patron. ${ }^{3}$

\subsubsection{Supervision: Hermes Schallautzer?}

In view of what we know of Strada's character, however, it is unlikely that he would have waited long before he obtruded his expertise and his opinions. Once he had spied out how the land lay and built up a good relationship with at least some of the architects and the decision-makers at court, we can expect to see some effects of his arrival. In particular his relationship with the Emperor's elder son, King Maximilian, would have strengthened his hand. By June 1559 he had built up a more personal relationship with the king, to whom he appealed

3 In a letter to Hans Jakob Fugger of 6 June 1559 Strada explains that he cannot respond in print to Lazius' invective for such reasons: 'Ma io mi bisogna molti rispetti avertire, perchè offenderei parechi in un tratto' (DOC. 1559-06-09). On the controversy, see above, Ch. 4.2. 
for help in the Lazius controversy, a relationship which would continue until Maximilian's death, and which was characterized by considerable mutual respect. ${ }^{4}$ Maximilian himself had already shown some interest in architecture and city planning and he was at least the nominal organizer of the festivities of 1560 . In later life, between his many more pressing political occupations, those devoted to building, gardening and festive projects at court provided a welcome recreation. Probably by this time he would have concerned himself personally in the architectural projects initiated by his father, whom he represented in his frequent absences: in particular in those projects intended to create or improve the accommodation for himself, his consort and his children and their households. But if so, we still do not know what form such involvement would have taken.

Deliberations such as that about the Hofspital seldom had an official status. As we have seen in the preceding chapter, they are very rarely documented, but that does not mean that they did not take place regularly, though the personal presence of Ferdinand in this instance probably was exceptional. In most cases Schallautzer, as Bausuperintendent, seems to have been responsible for the coordination of projects. Doubtless this included the communication between the Emperor and the architects and other artists involved in the projects under his supervision, so it is likely that formally Strada took his orders from Schallautzer; there is no evidence that Strada's attack on Lazius, Schallautzer's nephew, in any way interfered with their professional relations. Yet it is unlikely that Ferdinand and Maximilian would not have wished occasionally to hear their expert's opinions at first hand, just as it is unlikely that Strada would have accepted his position in Vienna, had he not at least occasionally been allowed to communicate his ideas or to present his designs to his patrons in person. This is indicated by Strada's confident letter to Archduke Ferdinand, insisting on the total control of the planned work; by his relative independence when employed by his first patron, Hans Jakob Fugger, with whom he still maintained a close personal relationship; and, later in his career, by the insistence of Duke Albrecht $\mathrm{v}$ of Bavaria on Strada's personal presence when he was planning the Munich Antiquarium. ${ }^{5}$

4 Copy of a letter by Strada to King Maximilian, enclosed in his letter to Hans Jakob Fugger of 6 June 1559, ibid. The letter to Fugger implies that Strada actually spoke to the king about the subject, before or when presenting his petition.

5 DOC. 1556-12-22: Strada to Archduke Ferdinand: 'Però volendo Sua Excellenza darmi il carico de tutto il lavoro, et ch'io abbia a comandare, et che non conoschi altro sopra capo che Sua Excellenza'. Strada's role in the genesis of the Munich Antiquarium discussed below, Ch. 8 . 


\subsection{The Tomb of Maximilian I in Innsbruck}

In August 1559 (or perhaps 1560, the year is not indicated) Jacopo Strada was again employed in a similar consultative capacity, now in connection with the most important dynastic commission of the Austrian Habsburgs, the completion of the tomb of the Emperor Maximilian I. This tomb had been planned by that Emperor himself and begun during his lifetime, and was intended to be placed in a chapel or mausoleum to be constructed after his own designs in the church of St. Georg in Wiener Neustadt. Its completion was enjoined on the Emperor's heirs in his will, and it naturally fell to Ferdinand I, as sovereign of the Austrian Erblande, to execute his grandfather's last wishes. He took this task quite seriously, but nevertheless did not manage to accomplish it within his own lifetime. The vicissitudes of this stupendous project have been described elsewhere; suffice here to note that by the time of Ferdinand's accession to the Empire the planned location of the monument had been shifted from Wiener Neustadt to Innsbruck, that a new church specifically designed to house it, the Hofkirche, was nearing completion, as was a large part of the huge array of over life-size bronze statues of historical and symbolical ancestors and precursors of the Habsburg Emperors that was to accompany the Imperial tomb proper. ${ }^{6}$

In 1555 or early in 1556 Ferdinand commanded Hermes Schallautzer to devise the collocation of the as yet inexistent tomb and the forty large and hundred small bronze statues and the thirty-two bronze portrait busts that were to accompany it in the new church. Schallautzer's report was accompanied by a ground plan of the new church showing the collocation of tomb and statues ( $\mathrm{nr} 9$ ), a ground plan (nr 3) of the tomb proper and a Visierung or design of one half of its elevation, showing 'how the whole should be ornamented' $(\mathrm{nr} 4) .{ }^{7}$ Schallautzer's description suggests that, like the accompanying statues, at least the historical scenes decorating the planned tomb or cenotaph were to be cast in bronze. ${ }^{8}$ It was to include all the coats of arms taken from

6 Actually it is a cenotaph, since Maximilian's remains were never transferred from Wiener Neustadt. On the history of the tomb, see a.o. Schönherr 189o; Oberhammer 1935; Dressler 1973, pp. 46-6o; EGG 1974, pp. 56-57; Scheicher 1984.

7 Schönherr 1890, p. 204; the text of Schallautzer's report to Ferdinand printed ibidem in appendix I, p. 264-265: 'So haben eur Römisch khgl. maj. etc. die gruntlegung der kirchen, darein das grab geseczt soll werden, mit austailung der 40 grossen bilder unden, desgleichen in de höch zwischen auf den pheilern di 100 clainen bilder und an der prust baider porkirchen die 32 prustbilder hieneben mit nr. 9.'

8 Ibidem, 'mer die vierundzwainzig haubtstuckh aus der ernportn mitzueschickhen, grösz, wie es in das grab gegossen soll werden $<\ldots . .>$ '. 
Dürer's Ehrenpforte, the huge set of engravings commissioned by Maximilian I to document his life and triumphs, and thus to perpetuate his 'gedachtnus' and the lustre of his dynasty. ${ }^{9}$ The tomb had a parallel function, so it comes as no surprise that the scenes from the life of the emperor decorating its sides were to be taken from Dürer's masterpiece as well-a copy of it in loose sheets was added to Schallautzer's despatch (nr 5). A selection of twenty four scenes had been made, and at Ferdinand's request Schallautzer had commissioned 'maister Frannczisco, erzherzogen Ferdinannd etc. maller' - that is Francesco Terzio- to work out one of these scenes in true size (nr 6) and, to have some choice, he had also asked a German painter, Hainrich Voghther, to prepare another one (nr 8). The epigraphs that were to identify the scenes were likewise taken from the Ehrenpforte, but had to be rendered into Latin, a task which had been undertaken by Ferdinand's chancellor for Austria, Hans Jakob Fugger's old friend Georg Sigismund Seld, whose labour was likewise added to the packet for the Emperor (nr. 7). A book of drawings documenting the older statues preserved in Vienna, for which Ferdinand has asked, had been lent out, and could therefore not be included in the file. ${ }^{10}$ The design Schallautzer added to this package must have been the one preserved in the Albertina and attributed to Francesco Terzio [Fig. 6.2], which implies that in 1556, though the coats of arms, the reliefs with the historical scenes and the statues placed on its cover were still planned in bronze, the tomb itself was already conceived to be executed in marble, 'there is no doubt $<$... >that the entire architectural structure of the tomb should in fact be executed in marble..11

Schallautzer's report shows the great interest Ferdinand attached to this project, and also how carefully and competently Schallautzer handled his master's commissions. It also makes clear that the material Schallautzer sent provided the basis for further discussion and decision making, for which Ferdinand would have recourse to others in his circle whose taste or whose

Both Ehrenpforte and tomb project are salient examples of a chapter in Maximilian's fictionalized autobiography Der Weißkunig: 'Wie der jung weiß kunig die Gedächtnus insonders lieb het'.

10 The Latin versions of the inscriptions printed in Schönherr 189o, pp. 266-268); the book of drawings can perhaps be identified with a preserved codex with drawings in watercolour from Jörg Kölderer's workshop [öNB-Hs Cod. 8329; cf. RUHM UND SINNLICHKEIT 1996, p. 163-164, cat. nr. 38 .

11 Oberhammer 1935, p. 62: 'es unterliegt kein Zweifel<...>daß das ganze Architekturgerüst der Tumba, tatsächlich in Marmor ausgeführt werden sollte'. The drawing tallies quite well with the description (24 panels, the coats of arms, the frieze offering space for the 'principall oder sumari epitavi', the principal inscription). The sober, correct style of its architectural detail is quite close to that in the background of Terzio's print series Imagines domus Austriacae. 


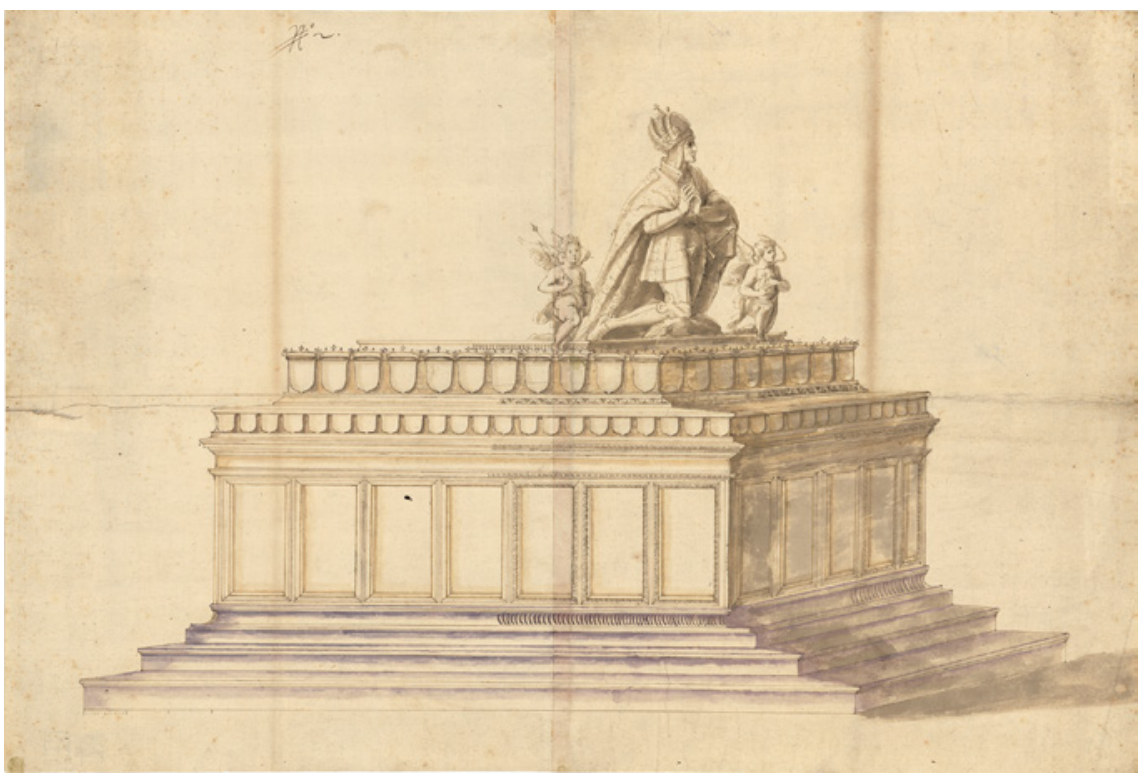

FIGURE 6.2 Attributed to Francesco Terzio, design for the tomb of Emperor Maximilian I, Innsbruck, ca 1555-1556; Vienna, Albertina.

historical, humanist, artistic or technical expertise could contribute to the desired result. Results probably were referred back to Innsbruck again, where the local government was responsible for the execution of the project and had to organize its finance. Thus in March 1557 Paul Uschal, secretary and 'Baumeister' of the Tirol government, was asked to come to Regensburg to show Ferdinand a 'visier' or design for the tomb. He was sent back with the instruction to have it drawn on true scale and pasted onto canvas. There things rested for a while, possibly because of the increased pressure of affairs due to Ferdinand's wish to ensure a smooth transition of power in the Empire after the abdication of Charles v. Two years later, in January 1559, Ferdinand asked the Innsbruck government to instruct Uschal to come and bring the promised 'visier', but it is not certain whether that had actually been made.

Later in this year, however, Schallautzer again reported on the matter to Ferdinand, who had asked him to discuss the design for the tomb with Pietro Ferrabosco, Jacopo Strada and Natale Veneziano, a meeting which took place on the $27_{\text {th }}$ of August. ${ }^{12}$ The report makes clear that a worked out design was

12 DOC. 1559-08-27; published in Schönherr 189o, Appendix II, pp. 265-266; the document itself is not dated, it may refer to a meeting on 27 August 156o, but 1559 seems more probable. 
available, and the discussion chiefly addressed the materials from which the several elements were to be made: the principal decision was to execute the historical scenes in white marble, rather than in bronze. But Schallautzer's summing up also shows that Terzio's relatively sober design had itself been changed or discarded: the tomb was to be flanked at the corners by four 'eghkhpilder' in bronze. It is not clear who was responsible for this new concept, which was worked out in a 'Visierung' or detailed design on true scale, an immense drawing in pen and wash pasted onto a canvas support-exactly as the Emperor had earlier asked Uschal to provide. Exceptionally this immense drawing (it measures over two by four meters) has been preserved in the Kunsthistorisches Museum [Fig. 6.3]. ${ }^{13}$ It is attributed to the painter Florian Abel, who was also responsible for the designs for the individual historical scenes that were commissioned from his two brothers, the sculptors Bernhard and Arnold Abel. These were employed on it for several years, and were paid a lot of money, but in the end realized only a few of the marbles cartouches carrying the captions of the scenes, and certainly not more than three of the reliefs.

Their greatest merit would be to recruit Alexander Colin from Mechelen as their assistant, who at the Abels's death would completely take over the project. He is responsible for almost all the sculptures decorating the entire tomb, including the kneeling effigy of Maximilian I, which was cast in bronze and placed only in 1583 . Though in the tomb as realized [Fig. 6.4] the reliefs and other elements such as the bronze armorial trophies along the top step of the podium are based on Florian Abel's designs, the architectural framework is simpler and seems to owe more to Terzio's sober, architectural proposal than

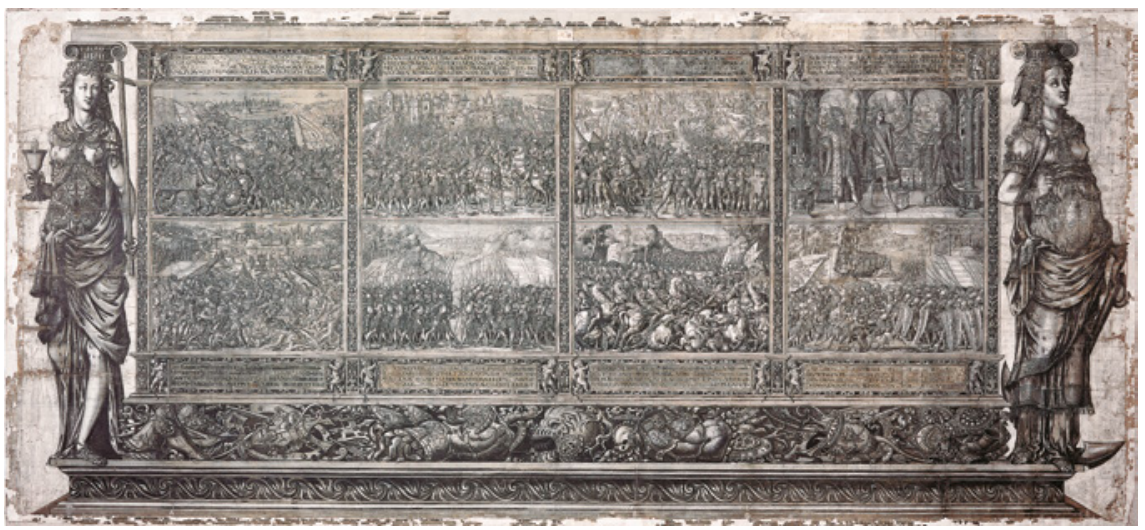

FIGURE 6.3 Attributed to Florian Abel, 'Visierung' or detailed life-size design for the tomb of Emperor Maximilian I, ca 1561; Innsbruck, Schloss Ambras.

Vienna, Kunsthistorisches Museum, Kunstkammer 4971. 


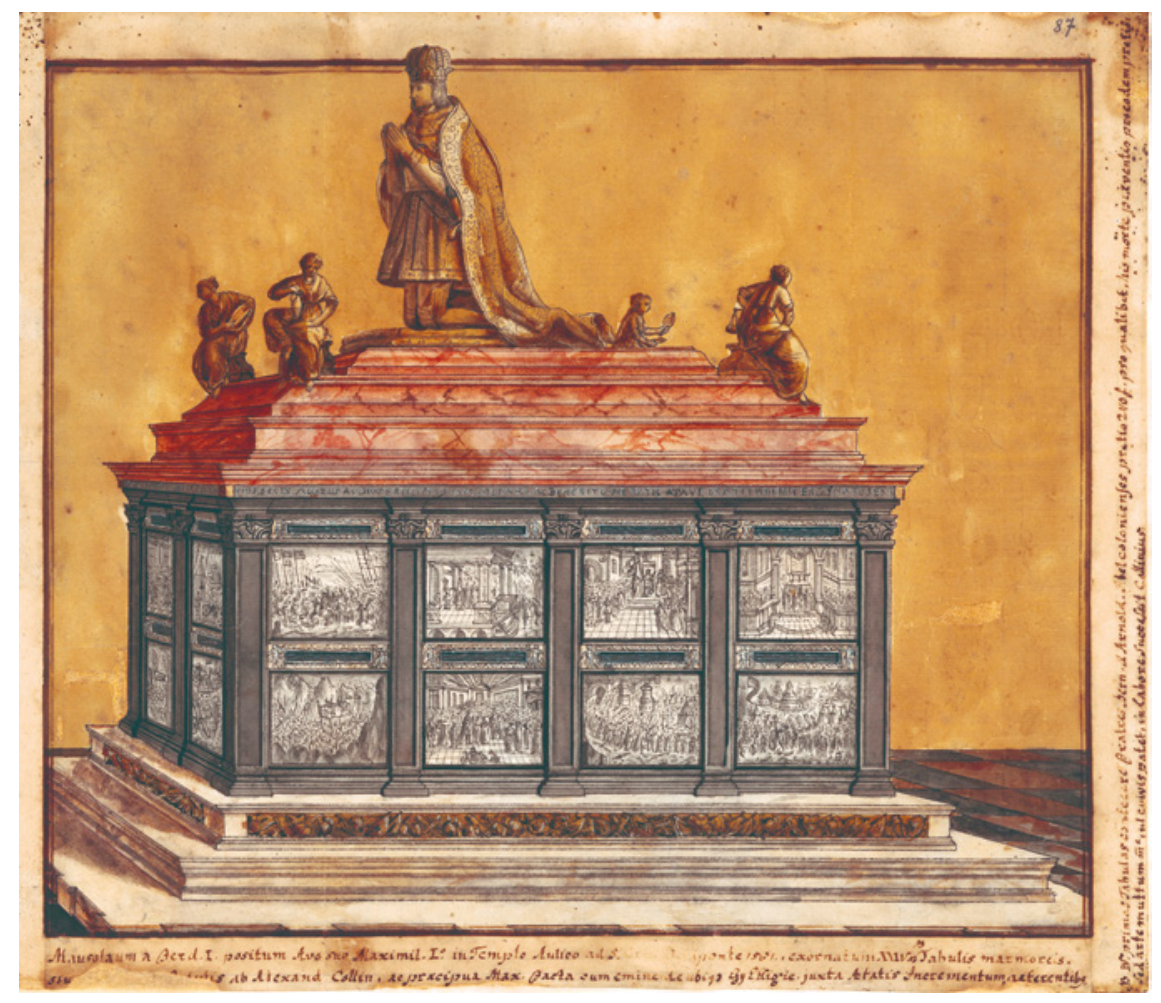

FIGURE 6.4 The tomb of Maximilian I as executed by Alexander Colin, drawing by Joseph Strickner 1744-1826; Innsbruck, Tiroler Landesmuseum.

to Abel's, which seems to derive from the art of the goldsmith, rather than from that of the architect. ${ }^{14}$

It is impossible to define with certainty what Jacopo Strada may have contributed to the conception or development of the Innsbruck tomb. It is significant for Ferdinand's attitude that all three artists he asked Schallautzer to consult were Italians: this implies that he wished for an up-to-date design which could hold its own when compared to similar projects, in Italy, but also in France and the Netherlands. Though all the members of the committee doubtless carefully considered and commented on all or most of the features of the plan, its insistence on the unity of design of the work may well be largely due to Strada:

14 Looking at the Visierung without background information I myself would suspect it to have been designed to be executed entirely in bronze, rather than in marble. The drawing by Joseph Strickner of the tomb as executed is in Innsbruck, Tiroler Landesmuseum Ferdinandeum, FB 1673 . 
$<\ldots>$ the design or Visierung of the tomb as a whole should absolutely be made by one hand, preferably the hand that made the design of the Emperor's person and the putti etc. on top of the grave. ${ }^{15}$

This passage provides a remarkable parallel to Strada's earlier advice in the matter of Archduke Ferdinand's table fountain, where he likewise insisted on the importance of a detailed, architectural plan or even a three-dimensional model, and one single 'supervisor who well understands the planned work, so that he can guide the masters employed in it.'16 Whether Strada would have pretended to such a function in the case of Maximilian's tomb is not clear, certainly there are no positive indications that he was further involved in it. All the same, being present at court as an acknowledged expert, it is not unlikely that he continued to contribute informally to the development of the project. Thus the classicist armorial trophies used as a socle zone in Abel's design [Fig. 6.6] may have been based on antiquarian drawings from his collection or even on Strada's own numismatics sketches [Fig. 6.5].

The similarity between the two caryatids at the corners of Abel's designpersonifications of the virtues of Faith and Hope-and some of the female figures in Strada's albums - particularly his renderings of antique statues-is

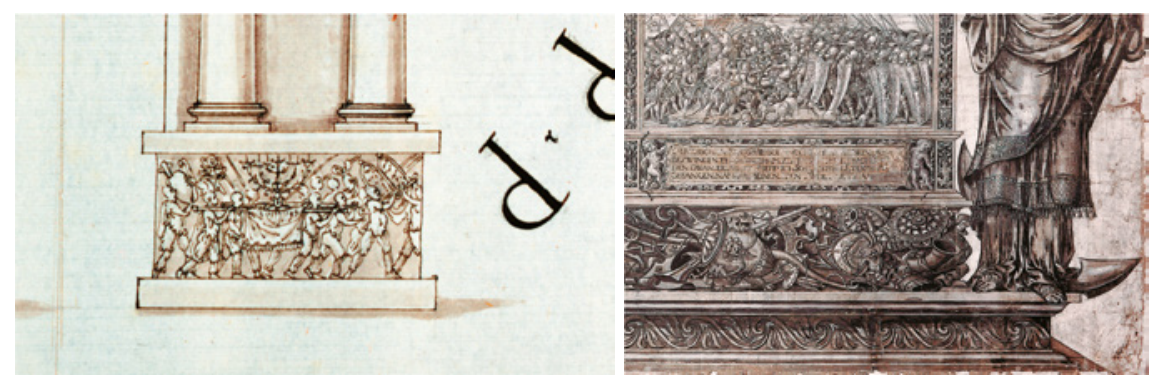

FIGURES 6.5-6.6 Jacopo Strada, detail of a reconstruction of a triumphal arch derived from a Roman coin (detail of Fig. 15.26), compared to the socle zone of Florian Abel's design for the tomb of Maximilian I (detail of Fig. 6.3).

15 Schönherr 1890, Appendix II, p. 265: 'Beschlieszlich soll die entwerfung oder visierung des ganzen grabs von ainer hand gemaht werden und fallen all der hant zue, so die kaiserlich perschon sambt den khindlen etc. auf dem grab entworfen hat.'

16 DOC. 1556-12-22: 'Et anche male in disegno si potra mostrare, per esser lavoro che pigliara molto spatio, et a volerlo dar ben ad intendere, bisognaria farne un modello, overo patrone, nel modo come si fa quando si vole edificar un palazzo, acciò che li maestri che lavorerano se ne possino servire. Anchora bisognaria che ci fusse un sopra capo, che intendesse il lavoro, acciò sapesse guidar li maestri; altramente l'opera andaria in una spesa infinita, et anche per aventura sarebe male a Sua satisfatione.' 
comparable to the resemblance between the latter and the supporting female in the Visierung for Jamnitzer's Merkelsche Tafelaufsatz discussed in Chapter 2.5 [Fig. 2.26]. Thus a drawing after the Flora Farnese (Naples) [Figs. 6.7] might have inspired one of Abel's Cardinal Virtues [Figs. 6.8], in particular because this statue at the time was also interpreted as Spes, or Hope, as is evident from the engraving of the same statue in Giovan Battista de' Cavallieri's print series Antiquarum Statuarum Urbis Romae Liber Primus, the earliest version of which is dated $1555^{-1561}$ [Figs. 6.9]. Even if this engraving, rather than Strada's drawing, was Abel's source, Strada's collection was still the most likely place for him to have found it. ${ }^{17}$ But more than antique precept these caryatides suggest the influence of contemporary mannerist examples, in particular French ones such as the caryatides of Goujon's famous musician's balcony in the Louvre of 1551 [Fig. 6.10]. Strada's own interest and expertise and his recent stay in France indicate him as the most likely channel through which such motifs reached the Imperial court.
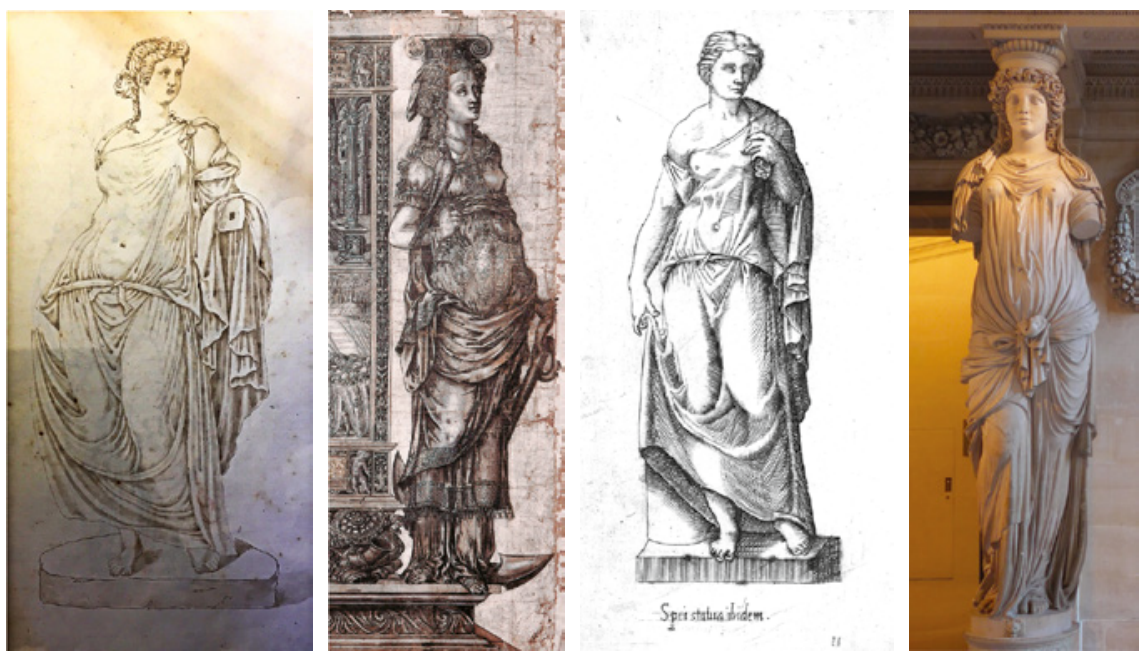

FIGURES 6.7-6.9 Jacopo Strada, drawing after the Flora Farnese (Vienna, Österreichsiche Nationalbibliothek) (6.7) and Giovan Battista Cavallieri's engraving of the same statue (as Spes) (6.9), compared to the caryatid personifying Hope in Florian Abel's design for the tomb of Maximilian I (6.8; detail of Fig. 6.3).

FIGURE 6.10 Jean Goujon, one of the Caryatides of his Tribune des musiciens in the Louvre, Paris 1551.

17 Strada's drawing in his Antiquarum Statuarum, Vienna, önb-HS, Cod. Min. 21,1, fol.12. On Cavallieri's print, see the relevant entry in the database Monumenta Rariora of the Scuola Normale Superiore in Pisa: http://mora.sns.it/_portale/scheda_fonte .asp?Lang=ITA\&GroupId=1\&id_txt=2792. 
On the other hand the design as a whole seems antithetical to Strada's approach: it seems pasted together of unrelated bits, its proportions and its architectural detail are old-fashioned, and seem Northern rather than Italian, in particular the puny lesenes separating the historical scenes [Fig. 6.3] which Colin later so rightly replaced by more substantial pilasters [Fig. 6.4].

But even if Strada did not contribute to the actual design of the tomb, as a member of the committee he may nevertheless have influenced the result. The decision to opt for marble rather than for bronze reliefs must have been chiefly due to him, as an acknowledged expert of classical antiquities, including sculpture. Being Italian, and having travelled widely in his country, he was moreover well equipped to contribute to the detailed instructions given to $\mathrm{Ar}$ nold Abel where to look for the right sort of marble: eventually it would be imported from Carrara. ${ }^{18}$

\subsection{Interior Decoration}

In deliberations such as those about the tomb for Maximilian I Strada doubtless illustrated his point of view by means of the graphic material he had brought together. It is quite tempting to see an example of such influence in the design of the ceiling of the grosse Taflstube already mentioned above, which must have been realized shortly before 1560 . In Chapter 5 we have seen that Strada was closely involved in the conception of the ceiling of the Goldene Saal in the Hofburg at Innsbruck, which was put together and painted by the painter Domenico da Pozzo in the second half of 1559.

It can be assumed that Strada would have played a similar role in the creation of the ceiling of the Vienna Taflstube, which was probably realized at about this same time [Fig. 6.13]. It is interesting to compare this ceiling with what we know of that of the Goldene Saal and with the slightly earlier similar ceiling in the 'Ritterstube' in the Vienna Hofburg, dating from ca 1550-1551 and possibly designed by Ferrabosco, who was paid for painting it [Fig. 6.11].

In these two cases the actual beams and wooden floors of the chambers above were already in situ, and the 'poden' had to be attached to the underside of the beams: it therefore consisted of a relatively shallow system of geometrically arranged wooden ribs framing polygonal compartments, the whole secured onto a surface of wooden boards fastened to the underside of the beams. An impression of technique and appearance of such ceilings is provided by a

18 Schönherr 1890, pp. 207-208. 
slightly later one from Dobrovice castle, dating from ca. 1578, which has been preserved in Švihov castle in Southern Bohemia [Fig. 6.12]. ${ }^{19}$ We have seen that Strada probably influenced the final appearance of the Innsbruck ceiling, by which it both became more up-to-date than originally planned and corresponded more closely to the Emperor's taste as demonstrated in the slightly earlier ceiling of the Vienna Ritterstube [Fig. 6.11].

The grosse Taflstube, however, seems to have been newly constructed or reconstructed at about this time, possibly in anticipation of the festive meeting of Ferdinand and his children, which was organized by Maximilian himself and was to take place in $1560 .{ }^{20}$ This afforded the opportunity of inserting a ceiling where the load-bearing beams remain visible and determine its disposition [Fig. 6.13]. The greater depth and the strong articulation of the square and octagonal compartments result in a powerful and monumental composition. As we have seen, it was deemed sufficiently remarkable to be

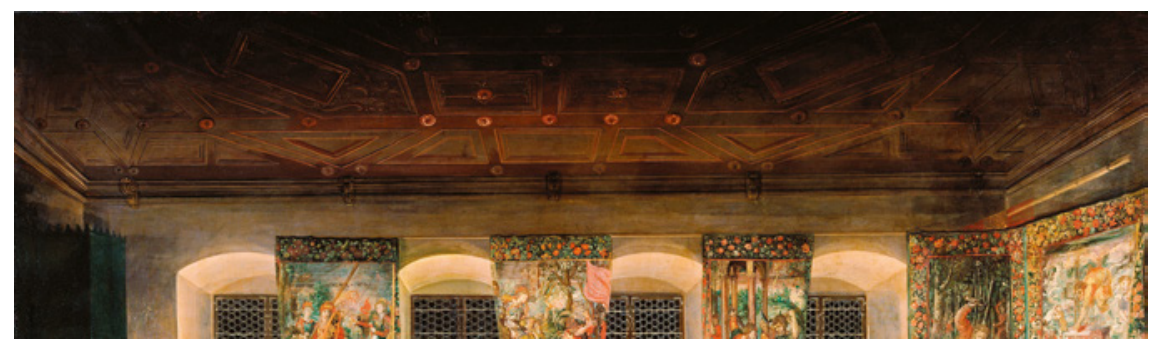

FIGURE 6.11 The ceiling in the Ritterstube of the Vienna Hofburg; detail of Fig. 5.76.

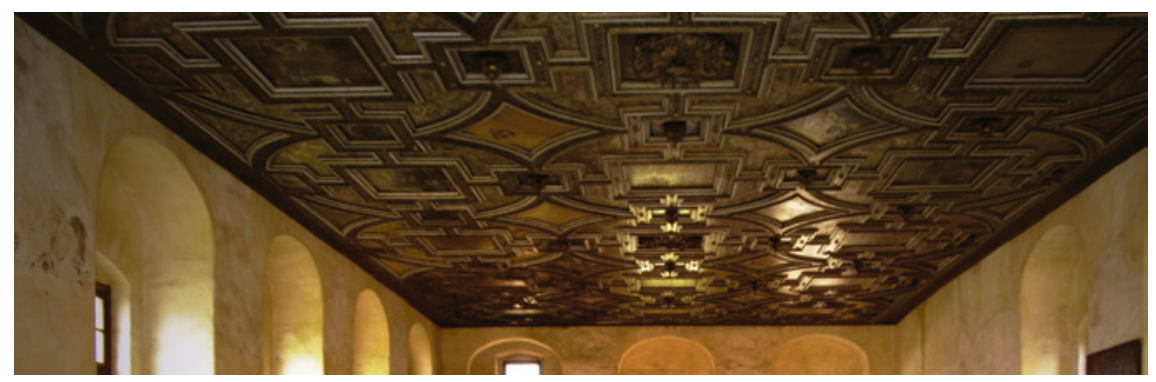

FIGURE 6.12 Ceiling from Dobrovice castle, ca 1578; now in Švihov castle, Czechia.

19 Kunst der Renaissance 1979, Abb. 57; Renaissance in Böhmen 1985, p. 210; another simpler example is the ceiling in Častolovice, ca 1580 (ibid., p. 210 and. pl. 166-168).

20 Possibly the Taflstube was created by merging two adjoining smaller rooms. 


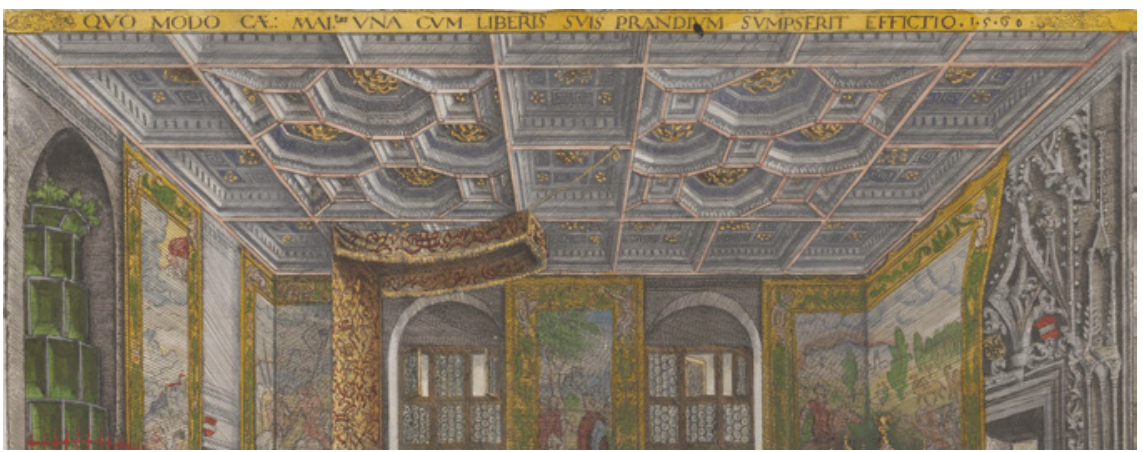

FIGURE 6.13 Ceiling of the grosse Taflstube in the Vienna Hofburg, rdetail of Fig. 5·75.

illustrated in detail in Francesco Terzio's print of what may have been the inaugural dinner of the Taflstube. ${ }^{21}$

Such ceilings had not only been illustrated by Serlio [Fig. 6.14-6.15], they had also been executed after his own designs, for instance in the library of the Ducal palace in Venice (1528-1531) and in the various rooms of the Castle of Ancy-le Franc, built after his designs in the mid-1540s. ${ }^{22}$ At this date, Strada was probably the only artist at court who knew such designs not only from paper, but had actually seen them executed in Italy and perhaps in France. It is very likely that the ceiling of the Taflstube, if it was not actually designed by him, was at least inspired by his collection of materials, in particular his Serlio manuscripts, and his comments on them.

\subsection{The Tanzhaus}

On the basis of its Serlian design the ceiling of the Taflstube can thus be tentatively linked to Strada. There are no data about other contributions to the conversion of the Hofburg proper. Most of the construction work had already been done, begun or at least planned before he arrived, and would have been too far advanced for him to have any influence on its architecture. I think it quite possible, however, that he did contribute designs for its interior decoration, in

21 Terzio did not quite grasp the structural base of the ceiling: in his perspective rendering the foreshortening reduces the width of the principal beams to narrow edges; though this might be possible, the small rosettes, indicated on their crossings, reflecting Serlio's designs, suggest that they were in reality wider.

22 Frommel 2002, pp. 186-199. 
AIN ANDER MANIER YON HIMLEN.

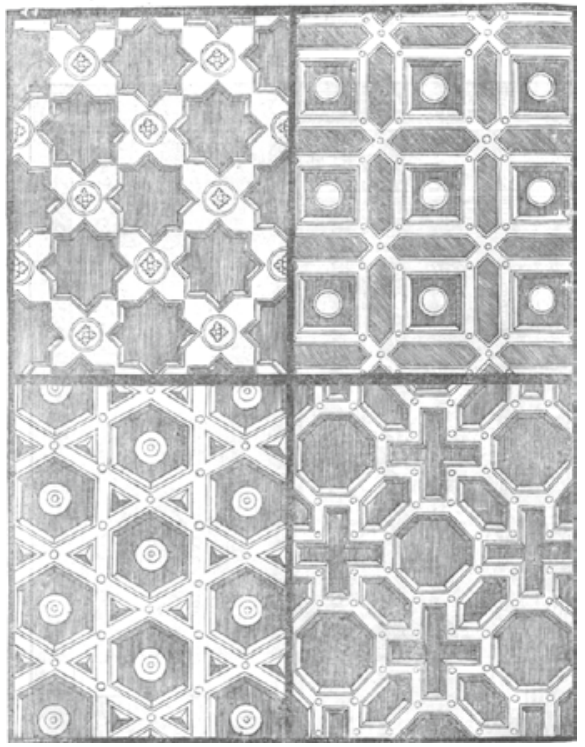

DAS III, BVCH CAP, XIL, Fart.

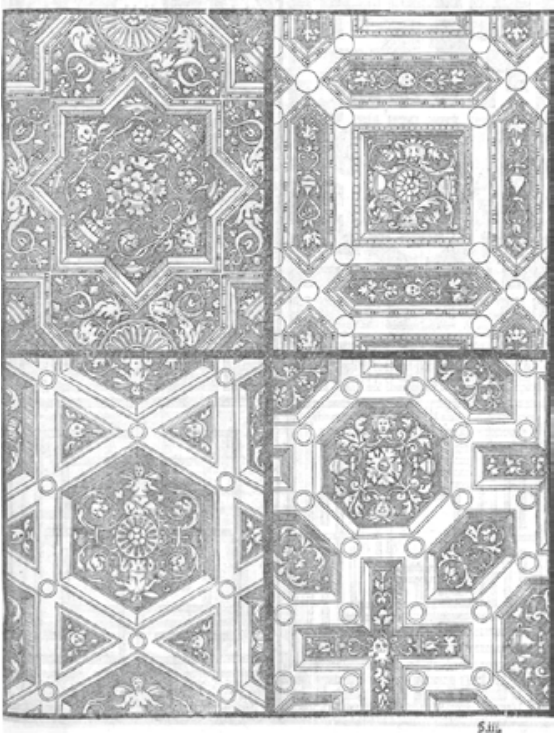

FIGURES 6.14-6.15 Eight designs for timber ceilings, from Sebastiano Serlio Die gemaynen Reglen von der Architectur uber die funf Manieren der Gebeu, Antwerp 1542 .

particular for ceilings, chimneypieces and doorways; his cosmopolitan experience and the materials of his Musaeum would make him the obvious person to provide such representative detailing. The importance of such necessarily trendsetting decoration has not been recognized because next to nothing of it has survived.

Likewise nothing has been preserved of the Tanzhaus, a temporary ballroom erected for the 1560 Habsburg family gathering on the Burgbastei, the bastion just in front of the Hofburg. But we do have an image of it: a print by an unidentified engraver, the monogrammist FA [Fig. 6.16] again preserved in Francolin's description of the festivities. ${ }^{23}$ Many artists must have been involved to prepare the designs for the various events, which included jousts and battles whose cartels were of an allegorical nature and based on legenadary tales of the gods and heroes of classical Antiquity.

Strada may well have been among them: we know that he did contribute to costume designs on at least two later occasions. Certainly Strada was sufficiently close to Hans von Francolin, the Imperial Herald who served as

23 Francolin 1561; Holzschuh-Hofer 2014(a), pp. 126-127. The plan is moreover visible in (the copy of) a plan of the Burgbastei by Pietro Ferrabosco, illustrated ibidem, Abb. IV.40. 


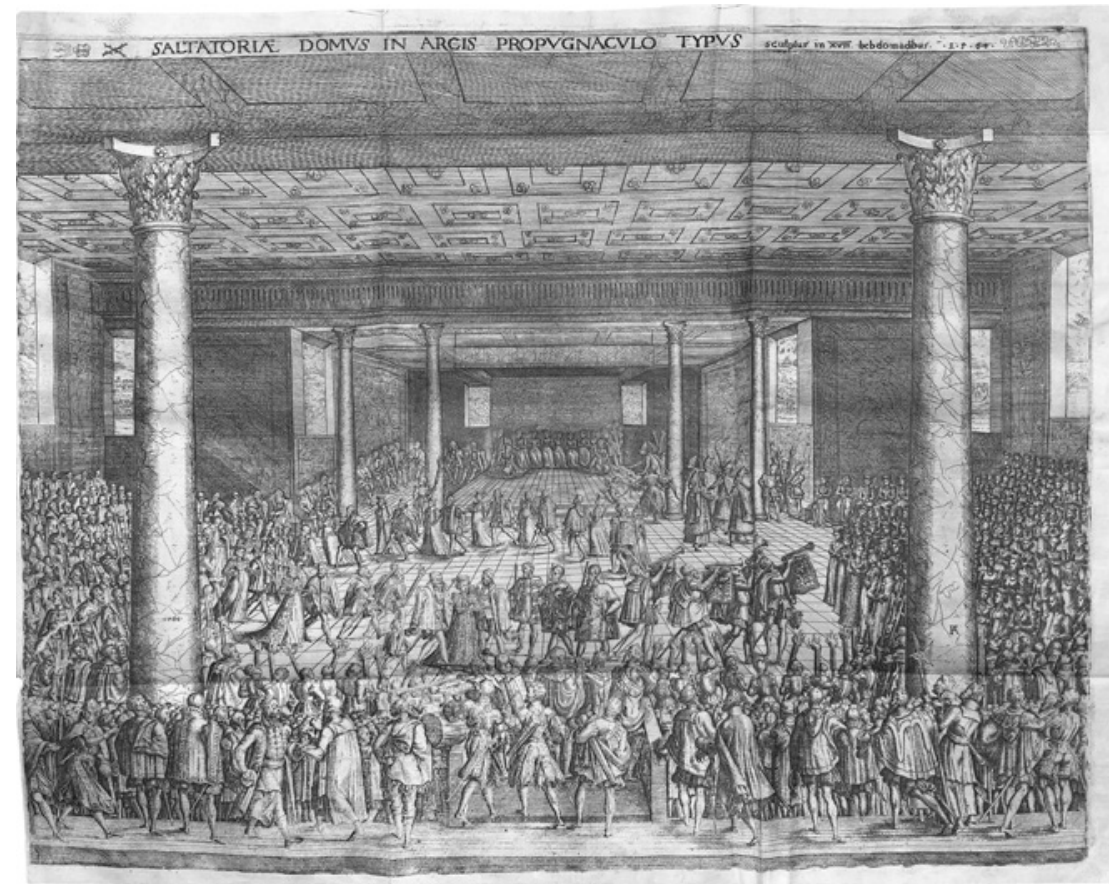

FIGURE 6.16 The 'Tanzhaus', a temporary ballroom constructed for the Habsburg family gathering in 1560; engraving by an unidentified monogrammist FA, from Hans von Francolin, Thurnierbuch... (1561).

master of ceremonies during the festivities, to provide him with the quick emblematic sketch that was inserted as frontispiece in Francolin's publication [Fig. 4.41]. ${ }^{24}$ And it is possible that he contributed to the design of the Tanzhaus itself: this was basically a huge tent or marquee, with a canvas ceiling imitating a compartmented ceiling similar to the one realized in the Taflstube, which was supported by sixteen tall wooden columns painted in faux-marbre and topped by gigantic Corinthian capitals [Figs. 6.16-6.17].

As an architect Strada was particularly equipped to design such elements, for which he could use his Serlio drawings and prints [Fig. 6.18]; as a goldsmith he could, moreover, provide a three-dimensional model for the foliage used in the capitals and for other ornament, to be used to create moulds in which to cast such ornament in stucco-it seems unlikely that sixteen of such capitals would have been carved in solid wood for a construction which was intended only for a few days' use. 

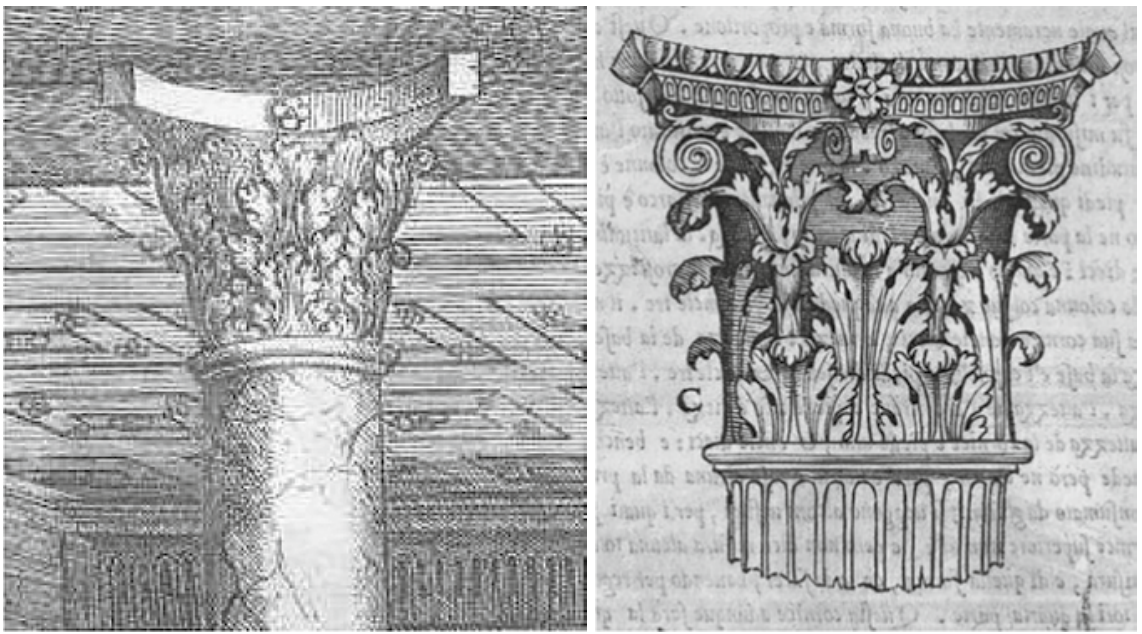

FIGURES 6.17-6.18 Detail of Fig. 6.17, compared to a Corinthian capital from the triumphal arch at Pola (Dalmatia), woodcut from Serlio's Terzo Libro, Venice 1544.

\subsection{The Stallburg}

By the time the Tanzhaus was constructed Strada had already demonstrated his knowledge and competence as an architect, reason why Ferdinand instructed the Hofkammer on 31 January 1560 that he had formally assumed him as 'ainem paumaister, bey unnsern gebewen alhier', at an annual salary of 200 Gulden. So Strada was particularly expected to contribute to the Emperor's projects in Vienna, chiefly the Hofburg, and this is confirmed by his appearance in a list of architects engaged on the Hofburg of $1562 .{ }^{25}$ Since Strada's salary was similar to that of other architects active in Vienna, Hilda Lietzmann concluded rationally that his task will not have remained limited to such occasional advice. She is the first to explicitly attribute to Strada the design of the Vienna Stallburg, the biggest single commission realized for the Emperor in the $1560 .^{26}$ Though it was an Imperial commission, it appears that Ferdinand delegated its supervision to his eldest son, King Maximilian, for whose use the building was intended. So it should be considered among Maximilian's earliest architectural commissions, as it certainly is the best preserved one, and it is of particular relevance for a better understanding of his patronage. ${ }^{27}$

25 DOCS. 1560-31-01 and 1562-00-00.

26 Lietzmann 1987, pp. 113-114.

27 Holzschuh-Hofer/Grün 2014 gives a complete survey of the building history of the Stallburg and an interpretation of its architecture. That Maximilian took the principal 
The construction of a new residential complex was very necessary, since the Hofburg proper offered far too little space to house the various members of Ferdinand's family and their households according to their rank. One solution was the acquisition, in 1559, of the house of Count Salm, opposite the Lustgarten, on the location of the present Palais Pallavicini on the Josefsplatz, as a residence for the Emperor's youngest son, Archduke Charles. A more rigorous solution, the construction of a completely new building, was decided upon to house Ferdinand's successor, King Maximilian, or more particularly, to house his horses: as we have seen, his own apartment was located in the so called Kindertrakt, immediately adjoining his father's chambers. The use of the ground floor to house the Imperial stables gave the new building its name 'Stallburg', which it still bears today, just as it still functions as the principal stable for the beautiful white Lipizaner horses of the Spanische Hofreitschule, Vienna's justly famous Spanish Riding School. But it also housed various other facilities - such as a kitchen, a coach house, the court's upholsterer's workshop - as well as commodious lodgings, which were probably reserved for higher-ranking members of the Imperial household and for important guests. In fact Hans Wincklmair, the secretary of Duke Albrecht $v$ of Bavaria, complained that 'it is such a lordly dwelling, that many say that it is a pity that His Majesty has it called like that'. So it does not surprise that the Duke asked to be housed in it, when he came to Vienna in 1571 to attend the wedding of his daughter Maria to Archduke Charles. ${ }^{28}$

The new building was constructed on a site between the Salm House and the church of St Michael, immediately opposite the Lustgarten. This site was cleared for the purpose, which made it possible to realize a huge residential building - its surface is about as large as the Hofburg proper — and to give this a regular appearance [Fig. 6.19]. ${ }^{29}$ Compared with other sections of the Hofburg complex, it has preserved its original structure more or less intact. It is a huge, regular building, consisting of three residential wings around a rectangular courtyard, surrounded by arcaded loggias on each floor, of seven bays on the short side, and nine bays on the long sides. The fourth wing, closing off the courtyard towards the former Lustgarten, is only as deep as the loggia

initiative is clear from an undated letter to his confidant Adam von Dietrichstein (cited p. 295). In view of the lack of concrete archival documents, Holzschuh-Hofer does not accept Lietzmann's attribution to Strada, but neither does she credit the executive architects, Pietro Ferrabosco and Antonio Continelli, with the actual design (p. 304, and n. 1608).

28 'ain so schöne herrliche hausung ist, dos vil sprechen, sei schad, das Jr Mt also nennen lassen'; cited in Holzschuh-Hofer/Grün 2014, pp. 302-303.

29 Ibid., pp. 294-295; Kühnel 1956, p. 259. It was while digging the foundations Schallautzer found the Roman inscriptions which were published by Wolfgang Lazius. 
itself. This is a building type that was current at the time in Southern Germany, Austria and Bohemia, and would remain popular at least until the end of the century. The arcaded courtyard or Laubenhof had its roots in late medieval castle architecture of the region, but the forms that developed in the sixteenth century were strongly influenced by Florentine and North-Italian Quattrocento architecture. In many cases such castles were in fact designed and built by North-Italian stonemasons and builders. The trendsetter was Schloss Porcia in Spittal an der Drau, the earliest Renaissance castle in Austria, built from 1534 for Gabriel Salamanca, the Spanish treasurer and influential courtier of Ferdinand I [Figs. 6.27-6.28]. The type is particularly richly represented in Bohemia. Examples are Litomyšl, Opočno, Bučovice, to name but a few. Many of these are of later date, and were probably influenced to some extent by the Stallburg itself. ${ }^{30}$

Though planned from the late 1550s, construction appears no to have begun until 1563. By the time of Ferdinand's death in 1564 it still was not completed: only in 1565 the masons Bärtlme Bethan and Antonio Pozo were paid for the construction of 'den obristen ganng umb und umb 27 Pögn' and a further seven arches 'bej dem Eingang neben der Erdt'. This implies that the original plan was for a U-shaped building enclosing a courtyard of seven by ten bays. This was closed off towards the Lustgarten by a fourth wing of only one story high, consisting of a loggia of seven bays; possibly (but unlikely) this may even have been open on both sides. Even if this reading of the document is right, this fourth, shallow wing was run up to full height at least before the end of the century, as is evident from Hoefnagel's 1609 bird's-eye view of Vienna [Fig. 6.20]. ${ }^{31}$
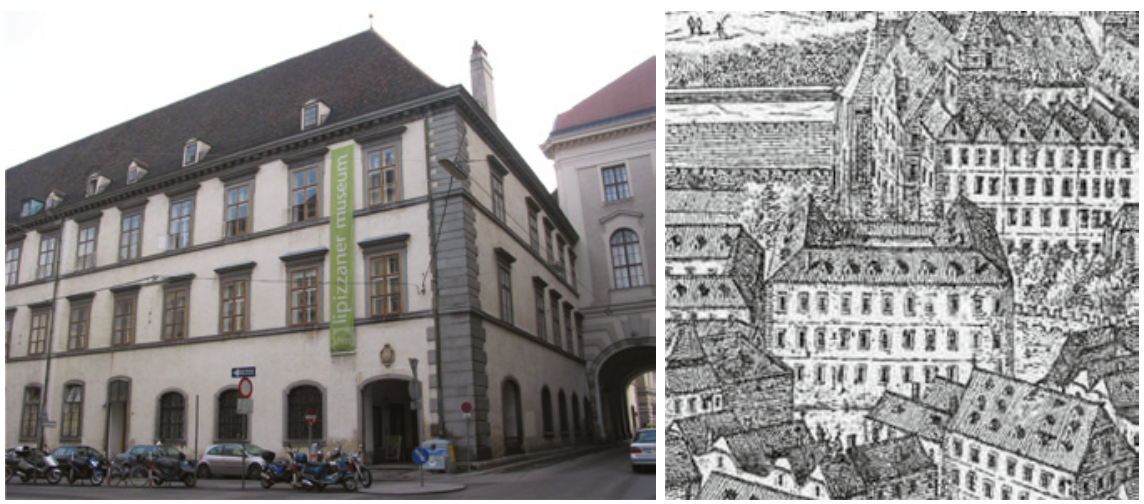

FIGURE 6.19 The Stallburg, Vienna, corner Reitschulgasse and Habsburgergasse. FIGURE 6.20 The Stallburg, in Jacob Hoefnagel's 1609 bird's-eye view of Vienna.

$30 \quad$ Plonner 1989; Rieger / Mitsch 1962.

31 Kühnel 1956, p. 215. The type of a U-shape arcaded courtyard closed off by a lower story on the fourth side became quite common in Bohemia in the later sixteenth century 
However traditional the building-type may have been for the region, the concept for the Stallburg also seems to owe something to the Serlio manuscripts and other material in Strada's possession. For instance Serlio's project for a 'palace in the countryside for an illustrious Prince in the French manner in his Sesto Libro [Fig. 6.21], which is closely related to his designs for Ancy-leFranc, seems to be quite close to the conception of Stallburg courtyard. ${ }^{32}$

The exterior of the Stallburg [Fig. 6.19 and 6.22] is well proportioned but very sober: it is articulated merely by the rhythm of the windows in simple frames, topped by straight entablatures and resting on the simple flat stringcourses dividing the stories. The most expressive elements are the dentilled cornice carrying the roof and the heavy quoins, diminishing towards the top, at the corners [Fig. 6.22]. Sources for these motifs are easy to find in Italian Renaissance architecture: significant instances are the Palazzo Adimari-Salviati, an early work (ca 1520) of Giulio Romano and therefore well-known to Strada [Fig. 6.24],

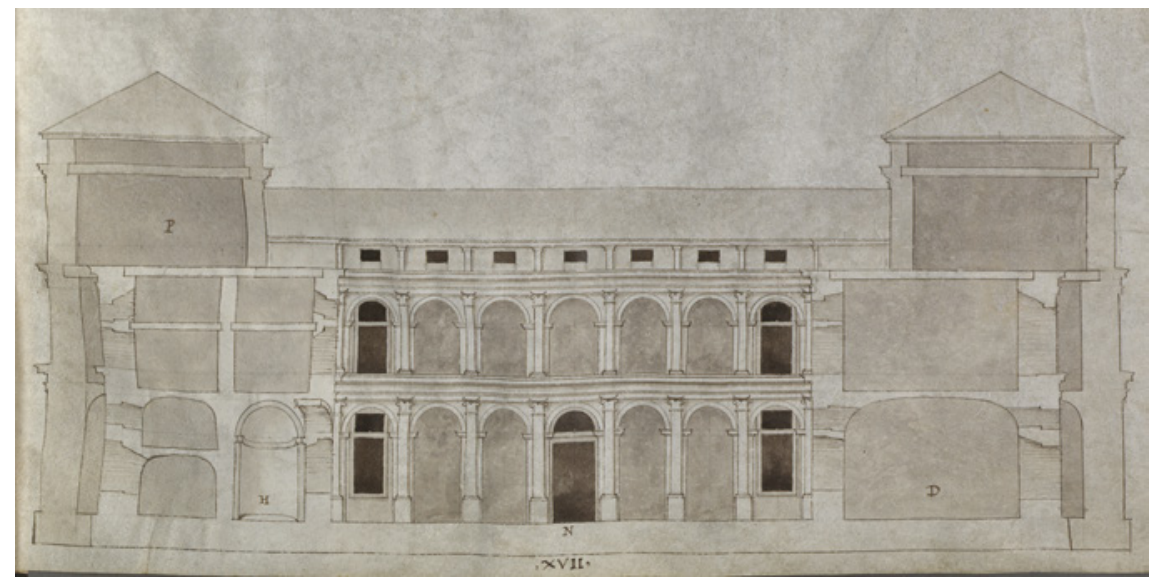

FIGURE 6.21 Sebastiano Serlio, project for a 'magione del principe illustre al modo di Franza', drawing from the Munich ms. of Serlio's Sesto Libro; Munich, Bayerische Staatsbibliothek.

(Litomyšl, Bučovice). Both on Jakob Hoefnagel's bird's eye view of Vienna of 1609 and on Suttinger's view of the 1683 siege of Vienna the arcades of the front wing appear to have been run up to full height, but since the front wing is less than half as deep as the other three, its roof was-and is-much lower.

32 Serlio's projected courtyard is only five bays square. The likeness would be even greater without the third story of the Stallburg, which as we have seen was probably added only after Maximilian had succeeded his father as Holy Roman Emperor. Perhaps initially an attic story as in Serlio's prototype may have been intended. 
and the design for a palace for a prince 'in the manner of a fortress', again in Serlio's Sesto Libro [Fig. 6.23]. ${ }^{33}$ It will be possible to cite similar correspondences in other elements of this and of other buildings discussed in this study.

In addition, the basically sober, unornamented architecture seems to own something to the quite functional designs in Serlio's 'Eighth' book. This was a project converting Polybius's description of a Roman castra, an army camp, into a permanent military settlement, a fortified garrison town. This in itself may have appealed to Ferdinand and Maximilian: Vienna was after all not only an Imperial residence, but also the most important citadel against the Turks, and the Hofburg itself an essential part of its fortifications, as had been proved in 1527 and would be proved again in $1683^{34}$ The choice for heavy, rusticated quoins on the outside corners, as in Serlio's 'Palazzo per un principe a modo di fortezza, noted above, reflects this preoccupation [Fig. 6.23]. In Serlio's Eight book, the plan and courtyard elevation of the foro or forum, one of the public buildings of his ideal garrison city, may have served as a source of inspiration [Figs. 6.25-6.26].
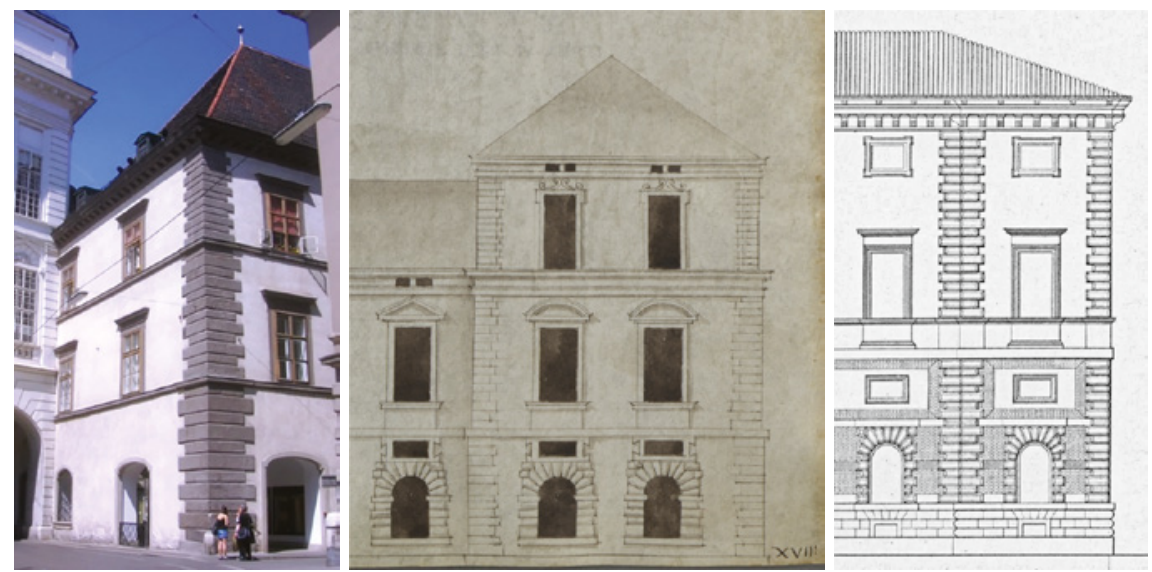

FIGURE 6.22 The Stallburg, corner at the Josefsplatz and the Bräunerstraße.

FIGURE 6.23 Sebastiano Serlio, Sesto Libro, project XVIII, 'Della casa del principe a modo di fortezza', detail; Munich, Bayerische Staatsbibliothek.

FIGURE 6.24 Giulio Romano, Palazzo Adimari-Salviati, Rome, detail; from Paul Letarouilly, Les Edifices de Rome moderne, 1857.

33 GIULIO ROMANO 1989, pp. 105-112; Sebastiano Serlio, Sesto Libro, Project XVIII, ms. München, вSв, Cod. Icon.189, fols.18v. and 18a-r., 'Della casa del principe a modo di fortezza'.

34 In addition, there may have been symbolic reasons to maintain the castle-like character of the Hofburg, cf. Müller 2000. 

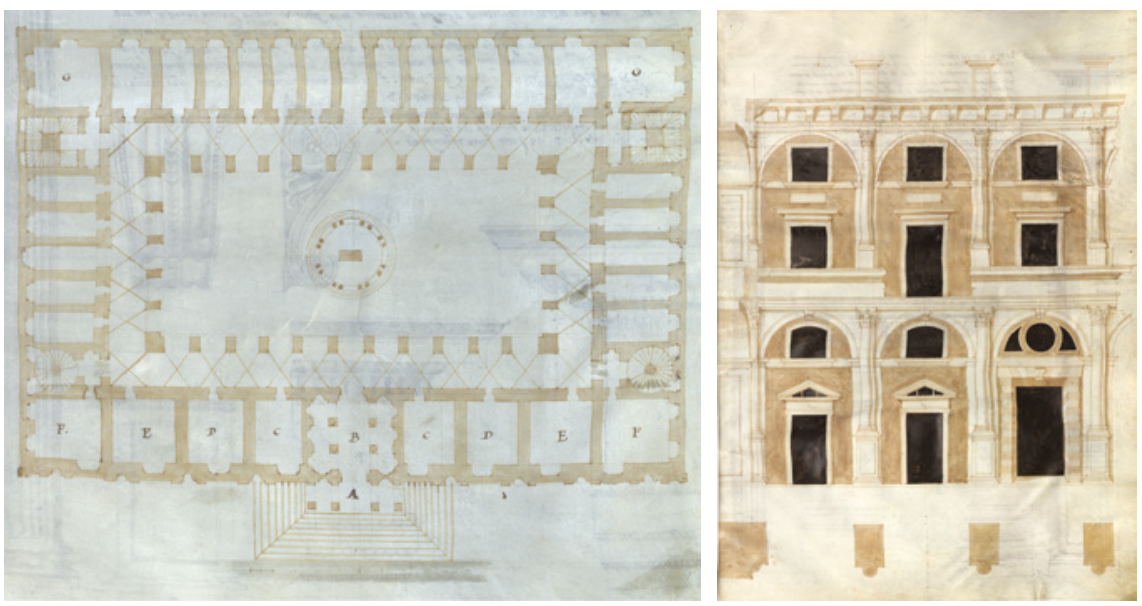

FIGURES 6.25-6.26

Sebastiano Serlio, 'Eighth' Book, project for a 'Foro', plan and courtyard elevation; Munich, Bayerische Staatsbibliothek.
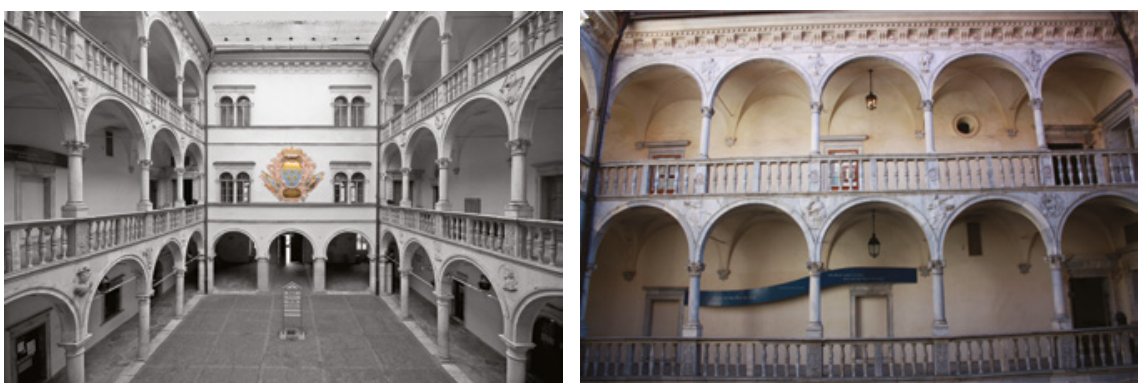

FIGURES 6.27-6.28 Schloss Porcia, Spittal an der Drau, courtyard, ca. 1535.

We have seen that the courtyard surrounded by arcades, the Laubenhof, was a current building-type for castles and public buildings in Austria and Bohemia. With rare exceptions these courtyards are based on the courtyards of early Renaissance palaces, that is, their arcades are carried on columns of a more-orless classicising aspect. The courtyard of the Porcia Schloss makes clear that, though its architect was conversant with the forms of classical architecture to some extent - the columns and their Ionic and Corinthian capitals, the balustrade-he was much less aware of the rules that should determine the relative proportions of these elements [Fig. 6.28-6.29]. ${ }^{35}$ Thus the columns are too short for their capitals, and certainly too short in relation to the width

35 The Porcia castle was built strictly according to a model left at the death of its patron, but was only completed towards the end of the century. In particular the design of the quite 


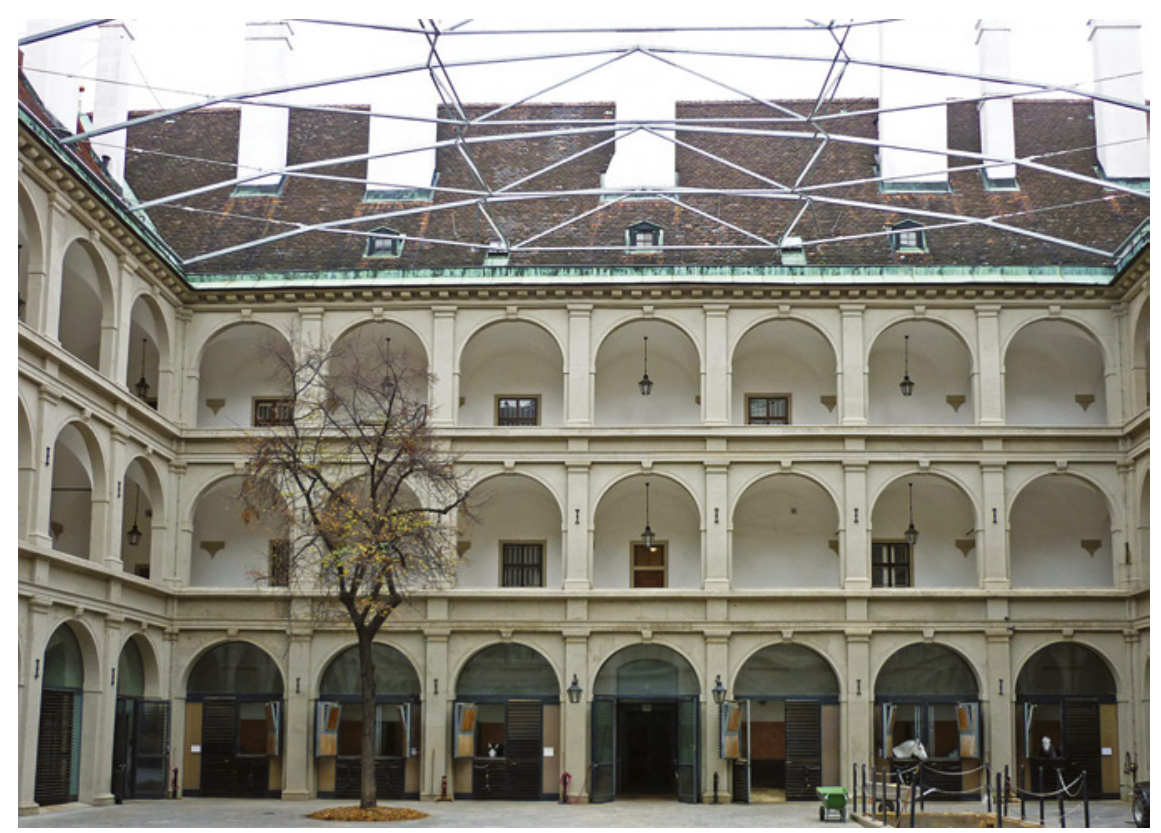

FIGURE 6.29 The Stallburg, courtyard.

of the arches they carry. Moreover, the very fact that the arches were carried on single columns instead of on piers or pilasters was by this time considered incorrect in Italy. ${ }^{36}$

The Stallburg is one of the earliest — if not the very first — of such courtyards in the region that does demonstrate a grasp of such rules [Figs. 6.29 and 6.31]. In the first place it should be noted that here the arcades are not carried on columns, but on square piers. To articulate the façade, an order of flat pilasters has been superimposed on these piers, in the manner that was best known from and was authorized by the facade of the Colosseum in Rome, such as it was illustrated, for instance, in Serlio's Third Book [Fig. 6.30]. The Colosseum, however, is a quite monumental, almost sculptural building, where the applied

impressive top frieze and cornice in the courtyard probably only dates from after 1584; cf. Rieger 1962, p. 105 .

36 Vitruvius does not even mention arcades - in his view, columns should carry architraves. In De Re Aedificatoria Leon Battista Alberti likewise argues that for structural reasons arches should be carried by square piers or pilasters, rather than by round columns. Late-Roman architecture deviates from this rule, as does early-Renaissance and Mannerist architecture. Certainly this critique does not imply that the Porcia Schloss is not a very satisfying, even exciting building when considered on its own terms-merely that it does not conform to the rules of Vitruvian architecture that had by this time become predominant in Italy. 
orders consist of half columns complete with splendidly carved capitals, resting on a pedestal zone and topped by a full entablature. The use of flat pilasters, however, was authorized by the example of the Roman amphitheatre in Verona, the Arena, likewise illustrated by Serlio [Fig. 6.32].

These buildings had already influenced the development of Renaissance architecture sufficiently to have been used as a source of inspiration in Vienna even without specialist champions such as Strada-Serlio's printed images and his comments would have been available in Vienna, even without Strada's presence. Nevertheless there can be no doubt that of the architects present at the Imperial court at this time, none had as profound a knowledge of such classical example as Strada: he knew these two amphitheatres not only from their illustrations in Serlio's Third Book, but had seen and studied them in detail himself.

In addition, the actual design of the Stallburg arcades reflects another source which can be traced to Strada's earlier experience and to his collection. The pilasters of the Arena in Verona are heavily rusticated and quite monumental, whereas those that articulate the Stallburg arcades are very refined in manner, with a flat, undecorated surface and very shallow relief: they hardly protrude from the wall surface and they are topped by the slightest of Tuscan capitals. The entablatures dividing the levels are likewise relatively shallow, and lack all habitual ornament. Only the top entablature is slightly stressed by the dentilled cornice, but it is incomplete, lacking both architrave and frieze. Like the
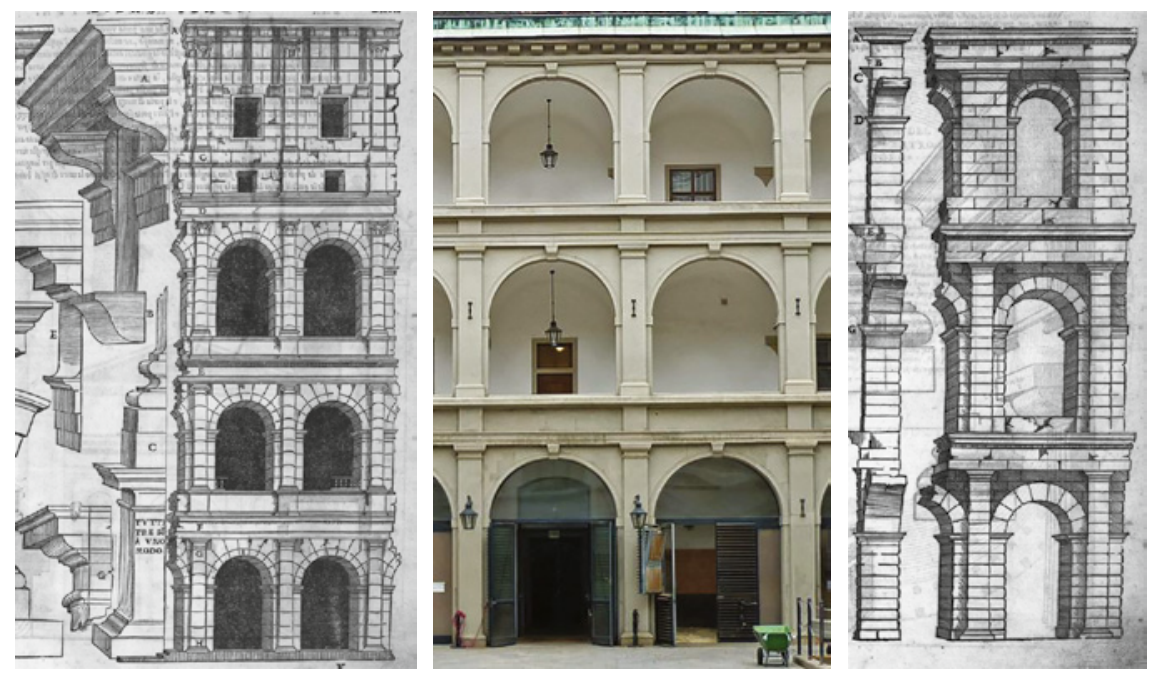

FIGURE 6.30 The Colosseum in Rome, woodcut from Serlio's Third Book.

FIGURE 6.31 The Stallburg, detail of courtyard.

FIGURE 6.32 The Arena in Verona, woodcut from Serlio's Third Book. 
heavily rusticated quoins on the exterior of the Stallburg, this highly refined, 'abbreviated' use of the classical orders in shallow relief points to Rome in the High Renaissance, and the early work of Giulio Romano in particular, such as the Palazzo Alberini and the Palazzo Stati-Maccarani [Fig. 6.33], as well as to Giulio's work in Mantua, such as the side-facade of the Basilica of San Benedetto in Polirone [Fig. 6.34] or the garden facade of the Palazzo del Te. ${ }^{37}$

The foregoing examples are not intended to identify the particular models actually and consciously used in preparing these designs of the Stallburgthey are too generic for such a purpose-but to sketch the artistic context in which these designs were conceived. Some of these examples and other similar instances-such as the illustrations in Serlio's first five books-could be known to, and have been used by, at least some of the architects active at the Imperial court even before Strada's arrival. For others, in particular the unpublished books of Serlio and the architectural designs of Giulio Romano, that is much less likely. Each of the several elements adduced here to stress the advanced, Italianate and classical character of the Stallburg might perhaps have been conceived by any of the local architects; but to find so many of these elements harmoniously combined in one building that can be considered as a competent, elegant and satisfying example of Renaissance design — though hardly as great architecture - strongly suggests that Strada had a hand in its conception.

When in 1577 it turned out that the roofs of the Stallburg were already ruinous, the Hofkammer thought it reasonable that the responsible 'Superintendent, Paumaister und Werckleute' should be made to reimburse from their own
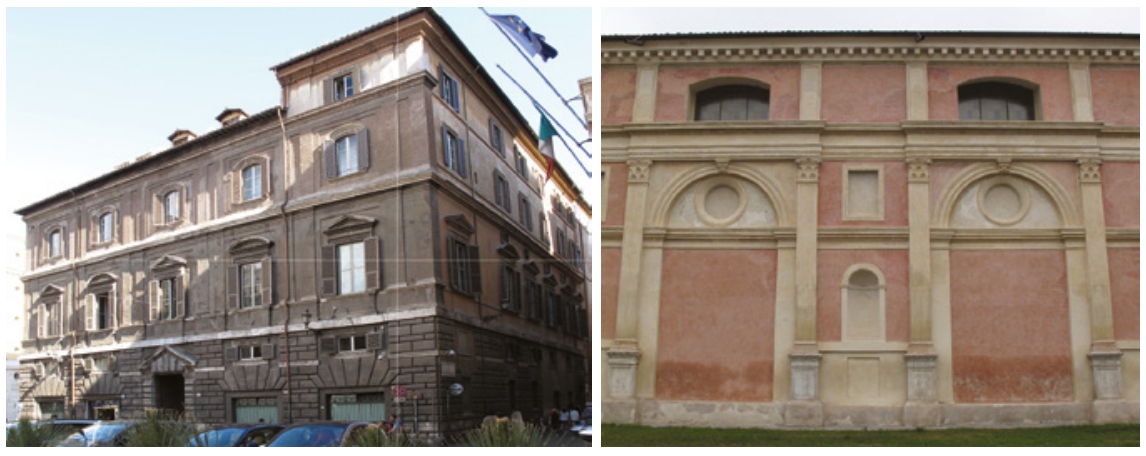

FIGURE 6.33 Giulio Romano, Palazzo Stati-Maccarani, Rome.

FIGURE 6.34 Giulio Romano, Basilica of San Benedetto in Polirone, side-facade.

37 GIULIO ROMANO 1987, p. 97-133 and 294-296. For a careful analysis of the Palazzo StatiMaccarani, see Rakatansky 2014. 
pockets the damage caused by their negligence; but they concluded that this was impracticable 'dieweil aber dieselben nunmer weiter nit vorhanden', that is, because they were no longer available. This was certainly true for the Bausuperintent Thomas Eiseler and the master masons Antonio Continelli, Bernhard de Camatha and Hanns Reckhendorfer, who all had died by 1577; but it was not true for Pietro Ferrabosco and for Jacopo Strada, both at the time still in Imperial service. In his essay on the Stallburg Harry Kühnel excluded both Ferrabosco and Strada as its supervising architect on the basis of this information. ${ }^{38}$ This may be true for Ferrabosco, whose intensive activity as a supervising, executive architect is quite well documented. But it cannot be upheld for Strada, who is never mentioned in such a capacity in the Vienna sources. Though Strada certainly was capable of making architectural designs, it is not certain that he possessed the technical know-how for supervising the actual construction work (as opposed to the execution of decorative work, such as painting, stucco and sculpture, in which he was competent, being trained as an artist and a goldsmith). ${ }^{39}$ As Hilda Lietzmann has indicated, he would not have been among the masters considered liable for the defects in its execution, and he remains therefore a serious candidate for the design of the Stallburg.

There is, moreover, another positive argument which links the design of the Stallburg to Mantua, and thus to Strada. This is a stylistic detail: the blocks placed in the frieze above each pilaster and prolonging it vertically, thus connecting the orders of the three levels. This is a rare motif already used, for instance, by Giuliano da Sangallo in the ground floor of his palace for the Florentine chancellor Bartolommeo Scala from the mid 1470s [Fig. 6.35]. More significant in this context, it was used in exactly the same way as in Vienna in the lower entablature of a house at Via Carlo Poma 22 in Mantua [Fig. 6.36]. This dates from the mid-sixteenth century and is traditionally attributed to Strada's exact contemporary and associate, Giovanni Battista Bertani. ${ }^{40}$

Even if we accept that Strada was the guiding spirit of the Stallburg project, on the basis of the information we have at present it remains impossible to

38 Holzschuh-Hofer/Grün 2014, pp. 296-297; Kühnel 1956, pp. 216-218. Ferrabosco himself was the one surviving master engaged in the building of the Stallburg from the beginning; Holzschuh-Hofer plausibly argues that he was not asked to reimburse the costs of the repairs because of his high standing; but it may also may indicate that he had not been responsible for the relevant part of the design and its execution, and liability would have remained with the contractors, the carpenters who had constructed the roof, or the tilers who had covered it.

39 It may be argued that Strada supervised the building of his own house himself, but even that is not sure; in any case the scale of that project was more modest than the Stallburg (cf. below).

40 Perina/ Pellati 1967; Carpeggiani 1992, pp. 95-96 (who does not accept the traditional attribution to Bertani). 

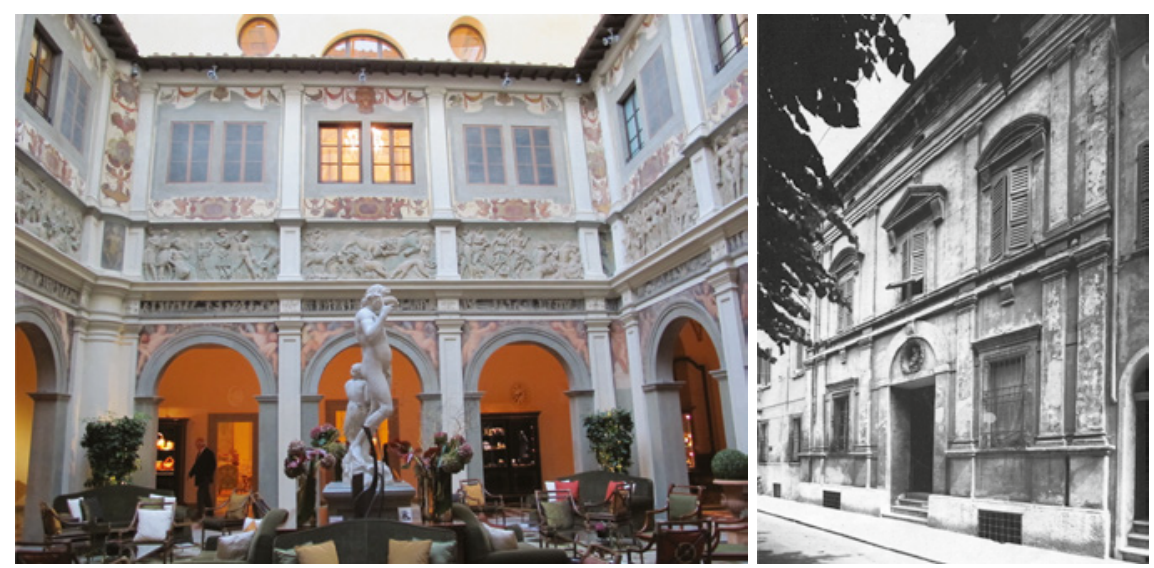

FIGURE 6.35 Giuliano da Sangallo, cortile of the Palazzo Scala, Florence, mid 1470 .

FIGURE 6.36 Attributed to Giovanni Battista Bertani, facade of the house house at Via Carlo Poma 22, Mantua, ca 1560 .

decide whether he provided a fully worked-out set of drawings to his patrons, who had them more or less faithfully executed by one of their professional 'Baumaister' such as Ferrabosco, or whether he merely helped a local architect to develop a more up-to-date design, providing sketches, making available his documentation and commenting on this, and coaching him in the actual design process. In view of the collective effort documented for other projects at court, to my mind the most likely scenario is that Strada did provide a basic concept for the building and detailed designs for the architectural and ornamental details, and perhaps even a three-dimensional model. These were then discussed in one or more consultations with his patron and his immediate colleagues, and subsequently modified according to his patron's wishes and to suit the technical and practical requirements posited by the Bausuperintendent and the Baumaister who were to execute it. Precedents for such a collective procedure are the various committees deciding on the ceiling of the Goldene Saal and the tomb of Maximilian I in Innsbruck, and the Hofspital in Vienna, discussed above. ${ }^{41}$

Its practical function obscures the fact that the Stallburg was the largest and most splendid residential building the Habsburgs had constructed ex novo within the walls of Vienna in the sixteenth century. It seems likely that the plans gestating for this new building in the late 1550 s provided the principal

41 Cf. above, Ch. 4.3.3.; 6.1. and 6.2. The use of models is documented for the Hofspital as well as for the Porcia Schloss. 
motivation for Ferdinand I to appoint Strada as a court-architect. It was in such projects that Strada's up-to-date knowledge of architecture and decoration in the grand manner could be most profitably employed, and the collection of documentation he kept in his Musaeum could be best exploited. Both as to its conception, its detailing and the timing of its planning, the Stallburg is the best candidate for an attribution to Strada. 